\title{
Jérôme Solal, Huysmans avant Dieu
}

\section{Ida Merello}

\section{(2) OpenEdition}

\section{Journals}

\section{Edizione digitale}

URL: http://journals.openedition.org/studifrancesi/6384

DOI: 10.4000/studifrancesi.6384

ISSN: 2427-5856

\section{Editore}

Rosenberg \& Sellier

\section{Edizione cartacea}

Data di pubblicazione: 1 novembre 2010

Paginazione: 578

ISSN: 0039-2944

\section{Notizia bibliografica digitale}

Ida Merello, «Jérôme Solal, Huysmans avant Dieu», Studi Francesi [Online], 162 (LIV | III) | 2010, online dal 30 novembre 2015, consultato il 13 janvier 2021. URL: http://journals.openedition.org/ studifrancesi/6384 ; DOI: https://doi.org/10.4000/studifrancesi.6384

Questo documento è stato generato automaticamente il 13 janvier 2021.

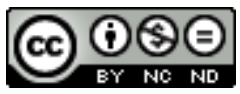

Studi Francesi è distribuita con Licenza Creative Commons Attribuzione - Non commerciale - Non opere derivate 4.0 Internazionale. 


\title{
Jérôme Solal, Huysmans avant Dieu
}

\author{
Ida Merello
}

\section{NOTIZIA}

JÉRÔME SOLAL, Huysmans avant Dieu, Paris, Classiques Garnier, 2010, pp. 230.

1 L'A. prende in considerazione la produzione di Huysmans che precede la conversione, ossia quella compresa tra il 1876 e il 1891, raccogliendo e organizzando interventi già pubblicati. Diviso in sezioni tematiche (Rue, Bruit, Tripes, Jupes ecc.) in realtà fa coincidere un testo di Huysmans per ogni sezione, orientando già in tal modo la lettura e offrendoci di ciascuno un'analisi pregevole. Il volume ha così il merito di riunire e di accordare ampio spazio a dieci opere come Marthe, Les soeurs Vatard, Sac au dos, En ménage, A vau-l'eau, Un dilemme, En rade, La retraite de M.Bougran, oltre naturalmente À rebours (presentato nella sezione Chambre) e Là-bas (Cène). 